\title{
報告 月0?
}

\section{日本風工学会第一回若手スクール報告 \\ Report of the First JAWE School for Young Members}

1.はじめに

今年の年次研究発表会の最終日(5月 28 日)ならびに 翌日 (5 月 29 日)に風工学を将来担う大学院生と若い研 究者の方々を対象に, 日本風工学会第一回若手スクー ルを東京大学で開催しました。

今回の若手スクールでは東京工業大学の田村哲郎教 授から「風工学と計算流体力学一現状と課題一」, 横浜 国立大学の勝地弘教授から「長大橋梁の歴史, 現状と 将来」と題して講義して頂くと共に, 講師の先生方の 実体験に基づき, 風工学の分野における研究課題およ び将来展望を教えて頂きました。スクールの後にはレ インボーブリッジの見学会を開催し, 大学院生 10 名, 社会人 10 名, 計 20 名の若手会員が参加しました。ま た 28 日の夕方には講師の先生方と若手との懇談会を 開催し，若手の研究紹介を行うと共に，親睦と交流を 行いました。具体的なプログラムを以下に示します。

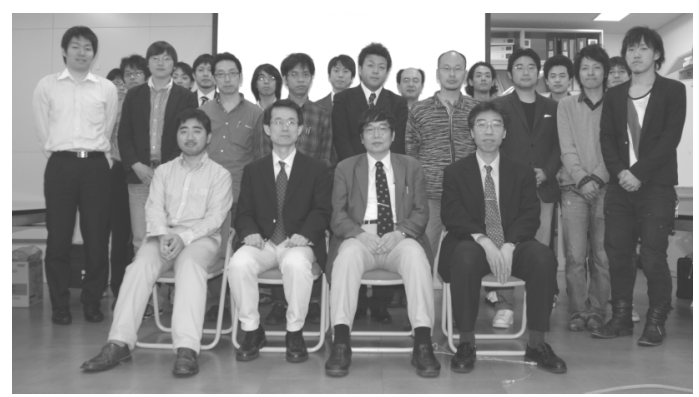

参加者の集合写真
石原 孟*1 山口 敦*2

Takeshi ISHIHARA, Atsushi YAMAGUCHI
プログラム :

5 月 28 日 夕方: 懇談会

○PS を用いた構造物の変位計測 吉田昭仁准教授 (東京工芸大学)

後流域の速度計測と FEM による数值流体解析 長谷部寛助手 (日本大学)

5 月 29 日 午前 : 講義

風工学と計算流体力学一現状と課題一 田村哲郎教授 (東京工業大学)

○長大橋梁の歴史, 現状と将来 勝地弘教授 (横浜国立大学)

5 月 29 日 午後：見学会

○レインボーブリッジの紹介と見学

\section{2. 若手スクールの紹介}

28 日の風工学年次研究発表会終了後, 日本大学から 東京大学に移動し, 若手と講師の先生との懇談会を行 いました。吉田先生, 長谷部先生に GPS を用いた構造 物の変位計測及び後流域の速度計測と FEM による数 值流体解析に関してプレゼンテーションをして頂きま した。プレゼンテーションに対して活発に議論が行わ れ，当初は 20:30までの予定でしたが，終了したのは $22: 30$ でした。

29 日の午前中には田村哲郎先生, 勝地弘先生により 講義して頂きました。田村哲郎先生には「風工学と計 算流体力学一現状と課題一」と題して数值流体解析に ついて講義して頂きました。LES モデルの歴史と定式 化について詳しく説明した後, ブラフボディ周りの流 れをLES によりシミュレートした例およびレイノル

* 1 東京大学大学院工学系研究科社会基盤学専攻 教授 Professor, Department of Civil Engineering, Univ. of Tokyo * 2 東京大学大学院工学系研究科社会基盤学専攻 助教 Assistant Professor, Department of Civil Engineering, Univ. of Tokyo 


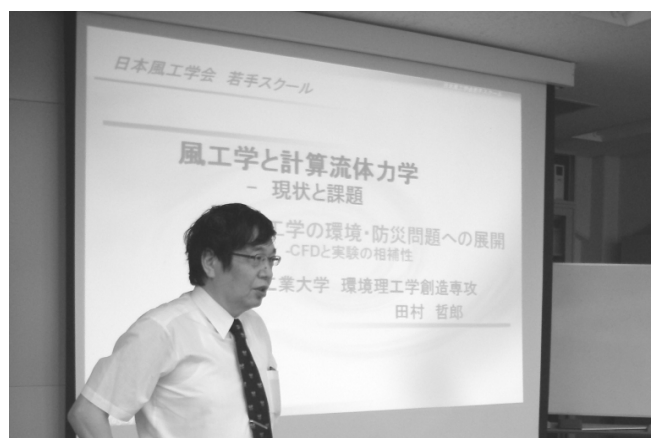

田村哲郎先生の講義の様子

ズ数や物体の辺長比によって流れや渦生成のパターン がどのように変わるかを説明して頂きました。また LES を用いた大気境界層内の流れのシミュレーション についても講義され, 大気境界層の解析に必要な変動 流入風を作成する手法や山越え気流のシミュレーショ ン結果について説明されました。さらに, 海風が実際 の市街地に吹きつける流れをシミュレーションした結 果についても説明され，高層建物群が海風の障壁とな り，高温領域が形成されることを示しました。

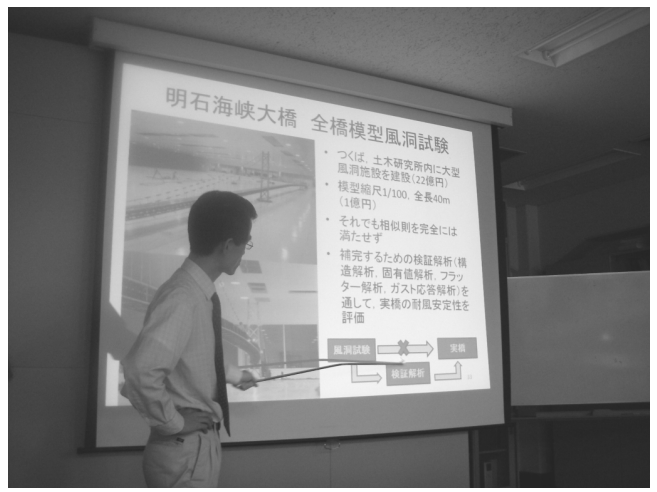

勝地弘先生の講義の様子

勝地弘先生には「長大橋梁の歴史, 現状と将来」と題 して講義をして頂きました。吊り橋・斜張橋の歴史から 明石海峡大橋までの風工学に関する設計上の問題点と 解決方法について説明して頂きました。講義では, 橋梁 に作用する風荷重が歴史的にどのように考えられ, 進歩 してきたかについて, 特に長スパンの吊り橋, 斜張橋の 歴史に焦点をあてて説明されました。テイ橋の落橋事故 にはじまり, 撓度理論の盲信によりタコマナロウズ橋が 落橋するまでの流れを詳しく説明し, 最終的に現在も用 いられている風洞実験と耐風設計に基づく吊り橋の設 計に至った経緯を説明されました。耐風工学の観点から
本四連絡橋を実現させた技術についても講義されまし た。吊り橋の耐風設計についてまとめた本州四国連絡橋 耐風設計基準の制定に始まり, 房総半島で実施された実 物の 10 分の 1 の断面模型による野外実験や, 明石海峡 大橋の設計風速設定のために神戸市垂水海岸に建設さ れた風観測塔による 20 年間にわたる長期風観測, 先に 竣工した大鳴門橋, 南備讃瀬戸大橋等での実橋計測によ る構造減衰の同定, つくばの土木研究所内に作られた大 型風洞での弾性模型を用いた実験などの研究プロジェ クトについて説明されました。講義の後には藤野会長に ご挨拶を頂き，午前中の講義を締めくくりました。

午後にはレインボーブリッジに場所を移して見学会 が行われました。レインボーブリッジは平成 5 年に供用 開始された全長 $790 \mathrm{~m}$ の 3 径間 2 ヒンジ補剛トラス吊り 橋です。最新の耐震工学知見から, 兵庫県南部地震クラ スの地震に対して部分的に損傷が生じる可能性がある ため，現在耐震補強工事を行っています。今回の見学会 では首都高速道路株式会社の方々にレインボーブリッ ジの耐風設計, メンテナンスおよび耐震補強工事などに ついて説明して頂いた後,「アンカレイジ」と呼ばれる 巨大なコンクリート構造物の中に入り, 普段目にしたこ とのない吊橋の世界を間近に見学させて頂きました。

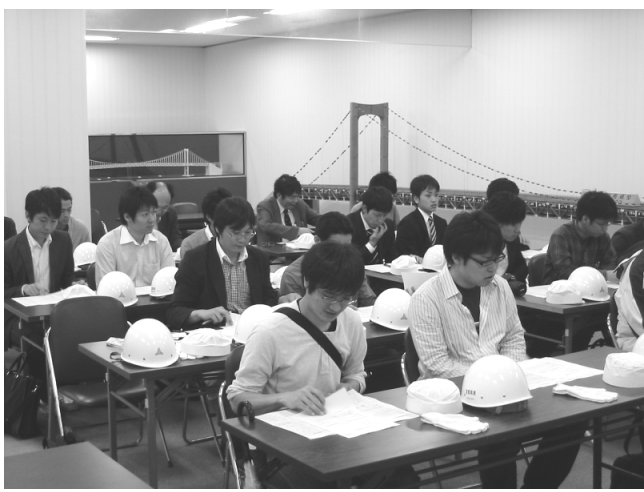

レインボーブリッジの紹介

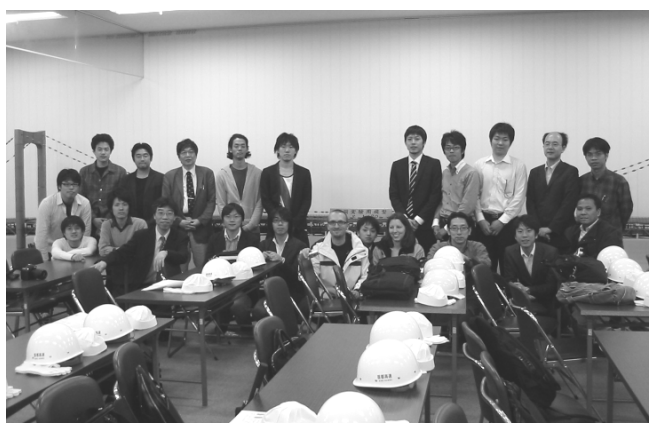

見学会参加者の集合写真 


\section{3. おわりに}

新型インフルエンザの影響で若手スクールの実施場 所が急遽大阪から東京に変更になっての開催でしたが, 皆様のご協力により第 1 回若手スクールは成功裏に終 わりました。参加者からは，「同世代の人とたっぷりと 議論できる機会があったのが大変よかった」,「先生方 の講義は専門外の人にもわかりやすく，とてもために なった」,「内容はすこし難しかったが，大変刺激を受 けた」などの感想を頂きました。来年も若手スクール が実施されることを期待いたします。

\section{謝 辞}

講義を引き受けて下さった田村哲郎先生, 勝地弘先 生をはじめ, 見学のお世話をして下さった首都高速道 路株式会社の高橋三雅様, 津野和宏様, 松原拓朗様, 福島忠様，また若手スクールの大阪会場および明石大 橋の見学会の準備にご尽力を頂いた大阪市立大学の谷 口徹郎先生, 本州四国連絡高速道路株式会社の楠原栄 樹様に感謝いたします。最後に若手スクールを提案し 支援して頂いた日本風工学会理事会の皆様に感謝申し 上げます。 